\title{
A review of Valeria Mosini's Reassessing the paradigm of economics: bringing positive economics back into the normative framework. London: Routledge, 2012, 164 pp.
}

\author{
PETER-WIM ZUIDHOF \\ University of Amsterdam
}

In this book, Valeria Mosini explores an interesting and daring thesis. She examines whether Milton Friedman's famous 1953 essay might not have had a solely methodological significance but may also have served a political purpose. The central claim of the book is that the methodological essay played a significant part in backing up Friedman's neoliberal policy prescriptions. His instrumentalist argument promoting the un-realisticness of assumptions and emphasizing prediction for testing theories, Mosini contends, effectively served to make his theoretical views immune to prior empirical scrutiny, and thus allowed Friedman to present what are essentially normative or political claims (his neo-liberal policy prescriptions) as a positive scientific paradigm for economics: "Friedman's methodological argument provided the neoliberal doctrine with the extra-bit that was required to turn it into a fully fledged paradigm awaiting implementation" (p. 4).

Mosini claims for instance that a number of Friedman's neoliberal prescriptions are insufficiently backed up by evidence that meets his own standards of scientificness. Even when Friedman's 'neoliberal' policy prescriptions did not live up to his own methodological standards, his methodological statements nonetheless served to lend them scientific credibility. Let me first briefly summarize how Mosini builds towards this claim in her book, before I note some of the major problems with her thesis.

In the first chapter, Mosini explores whether Friedman's neoliberal policy prescriptions actually abide by his own methodological standards. She does so by examining the logical consistency and validity of Friedman's Essays in positive economics (1953), which besides the famous essay on "The methodology of positive economics" also contains essays on economic policy. She first looks at whether the 'neoliberal' policy prescriptions contained in such essays as "The case for a flexible exchange rate" or "A monetary and fiscal framework for economic 
stability" were in fact arrived at in accordance with Friedman's own stated methodological views. Were Friedman's policy prescriptions based on theories whose predictions were anywhere tested, if they could be tested at all? Mosini shows that they were not.

Mosini further considers the validity of Friedman's claims and argues, for instance, that the essay "The effect of a full-employment policy on economic stability: a formal analysis", in which Friedman argues on the basis of a formal analysis that stabilization policy is in principle possible but likely not to be right in terms of timing or size, leaves much wanting in terms of both empirical evidence and even 'logical compellingness'.

She goes on to refer to the philosophical work by some of Friedman's contemporaries, such as Henry Margenau, Percy Bridgman and Stephen Toulmin, to suggest-not unsurprisingly-that Friedman also went against the view of the time which maintained that prediction cannot be a sufficient ground for evaluating theories. From these considerations about consistency and validity, Mosini then concludes that Friedman's policy prescriptions fail to live up to the methodological standards of positive science to make the bold claim that "given that Friedman must have been aware of the logical inconsistency that burdened Essays, his attribution of objectivity to the core theses of the neoliberal doctrine was based on false pretenses [sic]" (p. 34).

In the second chapter, Mosini moves to criticizing Friedman's positive-normative distinction by studying its historical origins. Even though Friedman opens the methodological essay with a quote from J. N. Keynes, Mosini claims that Friedman makes a mockery of Keynes' distinction. Mosini argues that whereas Friedman claims that positive economics could and should be pursued independently from normative economics, Keynes actually maintained that, especially with regard to policy advice, positive economics is always entangled in normative economics. This subversion of Keynes' distinction, Mosini contends, allowed Friedman to suggest that his positive economics is in fact free from normative or ideological considerations (p. 49).

Moreover, revisiting the work of contemporaries of Friedman, and also Alfred Marshall and especially Lionel Robbins, Mosini further highlights the singularity (and opportunism) of Friedman's use of the distinction. While for others the distinction mostly functions to argue that normative claims cannot be derived from positive statements alone, Friedman employs it to achieve exactly the opposite, which is to argue 
that it is indeed possible to offer policy advice based solely on positive economics which is supposedly purged of any normative consideration.

The third chapter is essentially concerned with a similar claim, but now Mosini draws on Léon Walras's account of the distinction between positive (or rather 'pure') economics, and his moral and applied economics in his Etudes d'économie sociale (1896) and Etudes d'économie politique appliquée (1898) respectively. In Mosini's reading, Walras's pure economics was inscribed in a larger normative framework. For Walras general equilibrium economics was not a natural order, but was a possible system for achieving the normative goal of social justice. Drawing on William Jaffé's translations and commentaries, she argues that Walras has been largely misconstrued, since the normative framework underlying his pure economics is generally disregarded. Mosini's interesting discussion of Walras is left hanging in the air, however, as she does not relate it back to the discussion of Friedman.

In the fourth chapter, Mosini returns to Friedman's methodology. She argues that part of the confusion arising from Friedman's essay can be attributed to a conflation of methodology as a branch of philosophy with methodology as being concerned with proper methods of scientific inquiry. Friedman has mostly been read in terms of the first, while according to Mosini he was concerned with the second. With regard to the question of methodology, Mosini asks whether Friedman should be described as a positivist, instrumentalist, pragmatist, Popperian, or Marshallian, and answers in the negative. Mosini goes on to consider whether Friedman's method, i.e., his way of scientific inquiry, conforms with the standards of scientific practice, by which she means the natural sciences. After a two-page comparison of Friedman's work on monetarism with the discovery of the chemical bond in chemistry, Mosini concludes that "Friedman's method as described and illustrated in his own theorizing did not reflect in any way the scientific practice" (p. 96). She ends by asking whether Friedman really believed in his own methodological practice or whether it mostly served to persuade economists and policy makers that his work was scientific.

In the fifth chapter, Mosini considers some of Friedman's substantive contributions to neoliberalism. Chapter 5 examines Friedman's claim in his popular book Capitalism and freedom (1962) that economic freedom promotes political freedom. She observes that Friedman nowhere in the book provides any evidence for this claim. Mosini reviews some research on the component questions of whether 
economic freedom results in economic growth, and whether economic growth promotes political freedom, to conclude that there are formidable issues with Friedman's claims. She also reviews two case studies, namely Pinochet's Chile and Mubarak's Egypt, and concludes that they present clear counter-evidence to Friedman's claims and that, certainly with regard to Chile, he should have taken notice of them. In her words:

The account given in this chapter of the many challenges brought to Friedman's apodictic claim that economic freedom promotes political freedom, and the evidence from specific case studies that can easily be generalized, revealed the existence of at least one blatant contradiction to the claim, the Chilean experiment, to which Friedman turned a blind eye (p. 119).

In the final chapter, Mosini tries to make a connection between the causes of the current financial crisis and Friedman's work on risk (e.g., Friedman and Savage 1948). It argues, somewhat haphazardly, that the neoliberal call to step back from markets and only come to the rescue when things turn bad, "was the natural development of [...] Friedman's treatment of uncertainty" (p. 135). More generally, the crisis in her view is very much the result of the divorcing of positive economics from normative economics as exemplified by Friedman's work: "Friedman's (1953) methodological paper did just that, killing two birds with one stone: attributing positive economics scientific status and objectivity, and, on that basis, subordinating to it normative economics, it ensured that regulations were informed not on ethics as traditionally understood but on 'market-ethics'” (p. 138). The economist's answer to the crisis, in Mosini's view, should return to the tradition of J. N. Keynes and Walras and again bring positive economics under the aegis of normative economics.

My general assessment of the book is that Mosini has potentially a compelling story to offer, but tells it poorly. Mosini asks an important question-is there a political significance to Friedman's methodological work-but she fails to offer a satisfactory answer. First off, I am afraid I have to say the book is poorly written. Sentences are convoluted and some contain grammatical errors (as the quotations given here demonstrate). This makes for a generally cumbersome read as one needs to continuously decipher what Mosini is trying to convey. 
More problematic is its composition. It is not always clear from the outset what the purpose of a chapter is, and chapters generally lack a clearly articulated conclusion. The order of the chapters is not really explained and it is unclear how the chapters build up towards a coherent conclusion. In fact, the book ends without a conclusion. And what, for instance, is the function of the third chapter on Walras for the larger argument of the book? This is too bad, because Mosini has great material for an important story.

Mosini's central concern is to expose Friedman for not practicing what he preached, and to show moreover that his preaching mostly served an ulterior, political purpose. Although I am quite convinced that Mosini is onto something important, her evidence is hardly convincing. From a cursory reading of two essays from his 1953 collection and a two page discussion of Friedman's work on monetarism, for example, she concludes that Friedman does not provide evidence for his theories in the manner prescribed by himself or the scientific community at large. Therefore, she claims, Friedman's theoretical prescriptions lack a sufficient scientific basis, and therefore his methodological essay primarily served a political function. These are strong claims, and in order to be convincing they require a much more thorough treatment of the evidence than Mosini offers.

In the fifth chapter for instance, Mosini rightly takes on Friedman's claim that economic freedom promotes political freedom, noting that Friedman offers no scientific evidence for this claim. But Mosini's counter-evidence consists of a few pages long empirical discussion of the question of whether economic freedom results in economic growth and, in the long-term, political freedom or democracy. This is sketchy at best. Citing the cases of Chile and Egypt (the choice of the latter is nowhere motivated) hardly constitutes compelling and sufficient counter-evidence to Friedman's thesis. If her aim is to disprove Friedman's claims about economic and political freedom, that requires a book-length refutation. Otherwise she falls prey to a similar charge of unscientificness. If you want to lecture Friedman about scientificness, your own work needs to have impeccable scientific standards.

As I understand it, the main point of Mosini's book, however, is to expose how Friedman's methodological views may unwittingly have lent scientific credibility to his neoliberal prescriptions and thus helped engender a 'fact-free' type of neoliberal politics in which the potential falsity of an economic theory's assumptions is irrelevant to discussions 
of its policy-applicability. I think this is a valid and important point. However, there is then no need to go all the way to disprove Friedman's economics. Rather than an all-out reckoning with Friedman's role in neoliberalism, Mosini should have stuck to meticulously charting and critiquing the political implications of his methodological arguments. Staying focused on what I take to be her real question could have saved Mosini from veering into gross overstatements of her case.

One of these overstatements concerns Mosini's account of Friedman's role in the history of neoliberalism. My concerns are firstly that Mosini nowhere explains what she means by neoliberalism, and secondly that she takes Friedman's role in it too much for granted. Neoliberalism is a highly elusive label (see Zuidhof 2012) and Mosini takes a little too easily for granted what it stands for and how Friedman is related to it. She presents neoliberalism as a strange amalgam of trade liberalization, monetarism, deregulation of finance, limited government, free markets, and a market-ethics, and makes it seem as if Friedman, in particular through his methodology, is singlehandedly responsible for all things neoliberal.

In other words, Mosini tends to equate neoliberalism with anything that came out of Friedman, turning neoliberalism into some sort of Friedmanism. That is a gross overstatement of the reach of neoliberalism, Friedman's involvement, and the purchase of his methodological argument. Not only is the history of neoliberalism much more complex and multi-faceted than Mosini makes it seem, the relevance of Friedman's methodological insights are much more subtle and intricate than her account allows. So Mosini unfortunately ends up grossly overstating the role of Friedman's methodology in the history of neoliberalism, while she could have a much more concise and credible point to make.

The really interesting question underlying Mosini's book therefore remains unfortunately by and large unanswered. Did Friedman's methodological essay serve a political purpose and how may it have been instrumental in fostering a neoliberal agenda? Why indeed did Friedman write this essay? Mosini is onto something when she relates Friedman's methodological views to his hawking of neoliberal precepts. The crucial point I learned from Mosini is that Friedman's methodological argument may have served to inoculate his economics from direct refutation by the facts, allowed him to present normative views as positive, and was thus conducive to supporting a kind of fact- 
free neoliberal politics. It is a missed opportunity however that Mosini did not provide the reader with a less overstated and more accurate account of how this came about.

\section{REFERENCES}

Friedman, Milton. 1953. Essays in positive economics. Chicago: University of Chicago Press.

Friedman, Milton. 1962. Capitalism and freedom. Chicago: University of Chicago Press.

Friedman, Milton, and Leonard J. Savage. 1948. The utility analysis of choices involving risk. Journal of Political Economy, 56 (4): 279-304.

Zuidhof, Peter-Wim. 2012. Imagining markets: the discursive politics of neoliberalism. PhD Dissertation. Rotterdam: Erasmus University Rotterdam.

Peter-Wim Zuidhof is assistant professor of European political economy in the Department of European Studies at the University of Amsterdam, the Netherlands. He recently defended a dissertation entitled Imagining markets: the discursive politics of neoliberalism (2012) at Erasmus University Rotterdam (the Netherlands) under the supervision of Arjo Klamer. His research focuses on the history and philosophy of neoliberalism and the place of economics therein.

Contact e-mail: <zuidhof@uva.nl>

Website: <home.medewerker.uva.nl/p.w.zuidhof> 